\title{
PERLINDUNGAN HAM PEKERJA MIGRAN: KAJIAN NORMATIF KEWAJIBAN INDONESIA BERDASAR PRINSIP-PRINSIP DAN NORMA-NORMA HUKUM INTERNASIONAL
}

\author{
Oleh: \\ Sri Lestari Rahayu, S.H., M.Hum. \\ Siti Muslimah, S.H., M.H. \\ Sasmini, S.H., LL.M. \\ Email: \\ r.srilestari@yahoo.com \\ she teauns@yahoo.co.id \\ sasmini.uns@gmail.com
}

\begin{abstract}
This research is conducted to get a legal argumentation related to responsibility of Indonesia on protection of its citizen, especially migrant workers. The question will be answered by determining the norms and principles that underlie Indonesia in protecting the human rights of its citizens. The sources of this research are international conventions, customary international law, doctrine, legal instruments in Indonesia and some of publications concerning the state responsibility to protect migrant workers. The legal sources collected by study documentation are analyzed by interpretation and content analysis. The results show that the general legal principles in which become basic of Indonesia associated with its obligation to provide protection of human rights of women migrant workers are based on the principle of nationality/citizenship of Indonesia, the principle of pacta sunt servanda, the principle of exhaustion of local remedies, the shift in meaning of the sovereignty principle and recognition principles theory of natural rights which inherent in every human being. While the norms are contained in the Migration for Employment Convention (Revised), 1949 (No. 97), the Convention on Migrant Workers (Supplementary Provisions), 1975 (No. 143), United Nations Convention on the Protection of the Rights of All Migrant Workers and Members of Their Families 1990.
\end{abstract}

Key words: human rights, migrant workers, obligations, international law

\begin{abstract}
Abstrak
Penelitian ini dilakukan untuk memperolah gambaran yang lebih mendalam mengenai tanggung jawab Negara Indonesia dalam memberikan perlindungan terhadap hak-hak warga negaranya, khususnya pekerja migran. Penulis mencoba menjawab permasalahan tersebut dari sisi normatif yaitu dengan mendasarkan pada norma-norma dan prinsip-prinsip yang mewajibkan setiap negara termasuk Indonesia untuk melindungi hak asasi warga negaranya. Bahan penelitian yang digunakan meliputi perjanjianperjanjian internasional, doktrin, hukum kebiasaan internasional, peraturan perundang-undangan di Indonesia, serta beberapa publikasi yang terkait dengan kewajiban negara atas perlindungan pekerja migran. Bahan hukum yang dikumpulkan melalui studi dokumen selanjutnya dianalisis melalui interpretasi teks dan analisis isi. Hasil pembahasan menunjukkan bahwa prinsip-prinsip hukum umum yang menjadi dasar Indonesia terkait dengan kewajibannya untuk memberikan perlindungan HAM pekerja migran didasarkan pada prinsip nasionalitas, prinsip pacta sunt servanda, prinsip exhaustion of local remedies, pergeresan makna prinsip kedaulatan dan diakuinya prinsip teori hak-hak kodrati yang melekat dalam diri setiap manusia. Sedangkan norma-normanya terdapat dalam Konvensi Migrasi untuk Pekerjaan (Revisi), 1949 (No. 97), Konvensi Pekerja Migran (Ketentuan-Ketentuan Tambahan), 1975 (No. 143), United Nations Convention on The Protection of The Rights of All Migran Workers and Member of Their Families tahun 1990.
\end{abstract}

Kata kunci: hak asasi manusia (HAM), pekerja migran, kewajiban, hukum internasional 


\section{A. Pendahuluan}

Perlindungan buruh migran merupakan bagian hak atas pekerjaan dan hak dalam bekerja yang merupakan hak asasi setiap manusia (HAM). Hakhak ini diatur dalam Pasal 23 Universal Declaration of Human Rights (UDHR) dan Pasal 6 International Covenant on Economic, Social and Cultural Rights (ICESCR) 1966 (Majda El Muhtaj, 2008: 182-183). Hak atas pekerjaan dan hak dalam bekerja sebagai bagian HAM akan melekat pada diri setiap orang, dan negara berkewajiban untuk menghormati, melindungi dan memenuhi HAM (Manfred Nowak, 2003:48). Kewajiban untuk menghormati berarti bahwa negara harus menjamin agar kebijakannya tidak melanggar HAM warga negaranya; melindungi dapat dilakukan dengan mencegah setiap pelanggaran yang dilakukan oleh pihak ketiga dan melakukan penyelidikan dan penghukuman bagi yang melanggar; sedangkan memenuhi berarti menciptakan suatu kondisi yang memungkinkan setiap individu menikmati hak atas pekerjaan misalnya dengan penyediaan informasi pekerjaan atau menciptakan lapangan pekerjaan (Margaret L. Satterthwaite, 2005: 11). Berdasarkan Pasal 2 ayat 1 ICESCR negara peratifikasi harus memenuhi kewajiban-kewajiban yang ditentukan dalam konvensi tersebut secara progresif.

Indonesia telah meratifikasi ICESCR melalui UU No 11 Tahun 2005 sehingga Indonesia berkewajiban untuk menghormati, melindungi dan memenuhi hak-hak yang diatur dalam konvensi tersebut, salah satunya adalah menyediakan lapangan pekerjaan dan akses informasi atas pekerjaan bagi warga negaranya. Namun demikian, karena kondisi perekonomian, lowongan pekerjaan yang tersedia di dalam negeri terbatas, tingkat kebutuhan hidup semakin tinggi telah menyebabkan banyak warga negara Indonesia yang mencari pekerjaan ke luar negeri. Jumlah pekerja migran tersebut dari tahun ke tahun semakin meningkat. Sebanyak 387.304 orang Indonesia per-tahun mencari kerja di luar negeri (Jorge Bustamante, 2006:2). Perkiraan jumlah pekerja migran dari Indonesia pada tahun 2010 mencapai 2.700 .000 orang (International Organization for Migration/IOM, 2010: 4).

Besarnya animo dan besarnya jumlah pekerja migran Indonesia tersebut di satu sisi mempunyai nilai positif, yaitu mengatasi sebagian masalah penggangguran di dalam negeri, namun demikian di sisi lain, besarnya jumlah pekerja migran juga mempunyai sisi negatif berupa resiko kemungkinan terjadinya perlakuan yang tidak manusiawi terhadap pekerja migran. Tenaga kerja migran sering dijadikan obyek perdagangan (trafficking), perbudakan, kerja paksa serta perlakuan lain yang melanggar HAM. Maret 2005 sampai dengan Desember 2010 tercatat 3.696 orang korban yang diperdagangkan, $90 \%$ adalah perempuan dan anakanak (International Organizational for Migration, 2010: 18). Pelanggaran HAM pekerja migran perempuan, khususnya pada sektor rumah tangga juga sering terjadi, hal ini karena perempuan adalah kelompok yang rentan terhadap pelanggaran HAM (Jennifer S Hainfurther, 2008: 4). Oleh karenanya, perlindungan HAM sangat diperlukan bagi pekerja migran perempuan.

Permasalahan yang akan dibahas dalam tulisan ini ada dua hal. Pertama, mengapa negara harus bertanggungjawab untuk melindungi warga negaranya, termasuk pekerja migran berdasarkan prinsip-prinsip dan norma-norma dalam hukum internasional?. Kedua, bagaimana bentuk tanggung jawab Indonesia untuk melindungi warga negaranya yang menjadi pekerja migran berdasar norma dalam hukum internasional khususnya hukum HAM internasional?. Secara rinci, untuk membahas permasalahan tersebut, artikel ini akan membahas tiga hal utama. Pertama, penulis akan membahas tentang konsep tanggungjawab dan kewajiban negara untuk melindungi warga negaranya (termasuk didalamnya adalah pekerja migran) dalam hukum internasional. Kedua, penulis akan menyajikan prinsip hukum internasional yang mewajibkan negara untuk melindungi hak pekerja migran. Ketiga, penulis akan membahas normanorma hukum internasional yang mewajibkan Indonesia untuk melindungi warga negaranya yang menjadi pekerja migran, khususnya adalah pekerja migran perempuan. Dan akhirnya artikel ini akan mencoba untuk memberikan suatu kesimpulan dan sejumlah rekomendasi atas tanggung jawab Indonesia untuk melindungi HAM pekerja migran, khususnya pekerja migran perempuan.

\section{B. Metode Penelitian}

Jenis penelitian yang penulis pergunakan dalam penelitian ini adalah penelitian hukum normatif. Bahan hukum yang digunakan adalah bahan hukum primer dan sekunder. Bahan hukum primer meliputi konvensi internasional, hukum kebiasaan internasional dan beberapa peraturan perundang-undangan di Indonesia yang mengatur pekerja migran. Sedangkan bahan hukum sekunder meliputi semua publikasi yang membahas kewajiban negara dan perlindungan HAM pekerja migran. Pengumpulan bahan hukum dilakukan dengan menggunakan studi dokumentasi bahan hukum.

Penelitian hukum merupakan suatu proses untuk menemukan aturan hukum, prinsip-prinsip hukum, maupun doktrin-doktrin hukum guna menjawab isu hukum yang dihadapi dalam rangka 
menghasilkan suatu argumentasi, teori atau konsep baru sebagai preskripsi dalam menyelesaikan masalah yang dihadapi (Peter Mahmud Marzuki, 2005:35). Pengumpulan bahan hukum dilakukan melalui studi kepustakaan dengan cara mengumpulkan bahan-bahan hukum yang relevan yang kemudian dilakukan identifikasi dan klasifikasi sesuai kebutuhan penulis. Dalam artikel ini, isu hukum penelitian diarahkan untuk menemukan norma dan prinsip-prinsip hukum yang mengatur tentang tanggung jawab negara untuk memberikan perlindungan terhadap pekerja migran perempuan. Untuk menjawab permasalahan tersebut maka bahan hukum dianalisis dengan menggunakan interpretasi dan analisis isi atas norma-norma hukum internasional.

\section{Hasil Penelitian dan Pembahasan}

1. Konsep Kewajiban dalam Hukum HAM Internasional

Kewajiban sering dimaknai sebagai keharusan untuk melakukan sesuatu. Dalam konteks HAM negara terikat kewajiban untuk memberikan jaminan perlindungan dan penghormatan hak asasi bagi setiap individu. Sejak diterimanya prinsip bahwa HAM tak dapat dibagi-bagikan (indivisible) dan saling bergantung satu sama lain (interdependent), secara perlahan-lahan kewajiban-kewajiban tersebut diterima negara-negara. Manfred Nowak menyebutkan kewajiban-kewajiban negara tersebut meliputi tiga hal yaitu berkewajiban untuk menghormati (obligations to respect), berkewajiban untuk melaksanakan (obligations to fulfill) dan berkewajiban untuk melindungi (obligation to protect) hak asasi manusia (Manfred Nowak, 2003: 48-50).

Obligation to respect HAM mengacu pada kewajiban untuk menahan diri dari intervensi negara. Kewajiban untuk menghormati adalah kewajiban untuk tidak mengintervensi pelaksanaan dan penikmatan atas HAM, dimana kewajiban ini mensyaratkan negara untuk menahan diri atas intervensi baik secara langsung atau tidak langsung atas penikmatan HAM. Penghormatan hak ekonomi, sosial dan budaya mewajibkan negara tidak membuat hukum, kebijakan atau tindakan-tindakan lain yang berpotensi melanggar HAM, serta mencabut hukum dan membatalkan kebijakan, tindakan-tindakan administratif serta program kegiatan yang tidak sesuai dengan ICESCR dan konvensi internasional lain (Manisuli Ssenyonjo, 2009: 23).

Kewajiban memenuhi mensyaratkan negara untuk mengambil tindakan legislasi, administrasi, penganggaran, yudisial, promosi dan tindakan-tindakan lain yang tepat/layak untuk menjamin terpenuhinya realisasi penuh atas hak ekonomi, sosial dan budaya. Kewajiban memenuhi ini dibagi menjadi tiga yaitu kewajiban memfasilitasi, mempromosikan dan menyediakan setiap sarana dan prasarana yang diperlukan menjamin terpenuhinya HAM setiap orang (Manisuli Ssenyonjo, 2009: 25).

Kewajiban melindungi mensyaratkan negara mengambil langkah-langkah yang mencegah aktivitas-aktivitas yang berpotensi melanggar HAM yang dilakukan oleh pihak ketiga baik individu, kelompok individu, korporasi, atau pihak lainnya dengan membuat dan mengimplementasikan kebijakan, peraturan perundang-undangan, keputusan pengadilan dalam kerangkan penegakan hukum. Negara berkewajiban mengambil langkah-langkah yang diperlukan atau melakukan upaya seoptimal mungkin mencegah, menghukum, menyelidiki setiap kerusakan yang disebabkan oleh pihak ketiga. Selain itu, negara berkewajiban memberikan upaya remidi dengan kompensasi, restitusi, rehabilitasi, pemuasan, dan jaminan untuk terulangnya peristiwa tersebut melalui amandemen UU atau penghapusan institusi tertentu (Manisuli Ssenyonjo, 2009: 24).

2. Prinsip-prinsip Kewajiban Negara Indonesia dalam Melindungi Pekerja Migran Perempuan

Prinsip hukum adalah pikiran dasar yang umum dan abstrak atau merupakan latar belakang peraturan konkrit dalam suatu sistem hukum tertentu. (Sudikno Mertokusumo, 2007: 5-11). Dapat dikatakan bahwa prinsip hukum merupakan landasan filosofis dalam suatu sistem hukum. Berdasarkan review bahan hukum prinsip-prinsip hukum umum internasional yang menjadi dasar kewajiban negara untuk memberikan perlindungan HAM pekerja migran perempuan adalah prinsip nasionalitas Indonesia, prinsip pacta sunt servanda, prinsip exhaustion of local remedies, pergeresan makna prinsip kedaulatan, dan diakuinya prinsip teori hak-hak kodrati yang melekat dalam diri setiap manusia.

a. Penerimaan Teori Hak Kodrati oleh Masyarakat Internasional

Berdasarkan sejarah historisnya, gagasan HAM sebenarnya bersumber dari teori hak kodrati (natural rights theory) yang bermula dari teori hukum alam (natu-

Perlindungan HAM Pekerja Migran... 113 
ral law theory) (Rhona K.M. Smith, dkk, 2008: 12). Hak kodrati melihat bahwa hak asasi manusia ada, terutama karena kodrat seseorang sebagai manusia, tidak tergantung pada afiliasi politik, ikatan kultural, agama, atau relasi sosial apapun, karena manusia adalah martabat yang terberi (given), sehingga unik dan tak tergantikan. Teori hak-hak kodrati tersebut memberikan kontribusi yang sangat penting atas pengakuan HAM. Teori tersebut menyerukan dan menegaskan untuk memberikan perlindungan HAM kepada setiap manusia dan memberikan jaminan untuk kebebasan dan kesetaraan bagi setiap manusia. Teori tersebut memberikan ruang bagi jaminan dan dukungan dalam sistem perlindungan hak asasi manusia, baik pada level domestik maupun internasional (Jerome J. Shestack dalam Rhonda L. Callaway, 2007: 22). Pencapaian tertinggi -teori hak kodrati adalah diakuinya manusia secara individu sebagai subyek yang diberkahi hak-hak dalam masyarakat dan menempatkannya dalam sistem hukum dan sosial masyarakat. HAM tersebut merupakan hak-hak alamiah yang melekat dan tidak dapat dicabut oleh siapapun (Manfred Nowak, 2003: 9).

Pada awal munculnya gagasan teori hak kodrati banyak dipersoalkan batasbatas kekuasaan para raja dan para ulama gereja yang masing-masing mengklaim bahwa kekuasaannya bersifat mutlak dan segala titah-titahnya bersifat universal dan mengikat siapapun (Soetandyo Wignjosoebroto, 2005:2). Berdasarkan hal tersebut salah seorang kaum terpelajar pasca-renaisans, Thomas Paine, Jean Jacques Rousseau, John Locke dan filsuf lain pada abad 17 dan 18 mengajukan pemikiran mengenai teori hak-hak kodrati. Negara sebagai wakil Tuhan di dunia yang diberikan mandat untuk menjaga ketertiban, apapun yang dilakukan sematamata untuk untuk melindungi hak-hak kodrati setiap individu, yaitu hak untuk hidup, kekebasan, keamanan, kekayaan, kebahagiaan dan lain sebagainya (Manfred Nowak, 2003: 9). Dalam bukunya, "The Second Treatise of Civil Government and a Letter Concerning Toleration" Locke mengajukan sebuah postulasi pemikiran bahwa semua individu dikaruniai oleh alam hak yang melekat atas hidup, kebebasan, dan kepemilikan, yang merupakan milik mereka sendiri dan tidak dapat dicabut atau dipreteli oleh negara. Melalui suatu 'kontrak sosial' (social contract), perlindungan atas hak yang tidak dapat dicabut ini diserahkan kepada negara. Tetapi menurut Locke, apabila penguasa negara mengabaikan kontrak sosial itu dengan melanggar hak-hak kodrati individu, maka rakyat di negara itu bebas menurunkan sang penguasa dan menggantikannya dengan suatu pemerintah yang bersedia menghormati hak-hak tersebut. Melalui teori hak-hak kodrati ini, maka eksistensi hak-hak individu yang pra-positif mendapat pengakuan kuat (Rhona K.M. Smith, dkk, 2008: 12). Gagasan Locke mengenai hakhak kodrati inilah yang melandasi munculnya revolusi hak dalam revolusi yang meletup di Inggris, Amerika Serikat dan Perancis pada abad ke-17 dan ke-18.

Namun demikian, pemikiran mengenai hak-hak kodrati ini banyak mendapat tentangan dari filsuf lain antara lain Edmund Burke, Jeremy Bentham, John Austin. Burke menuduh para penyusun "Declaration of the Rights of Man and of the Citizen" mempropagandakan "rekaan yang menakutkan mengenai persamaan manusia". Walaupun banyak mandapatkan tentangan, teori hak-hak kodrati tidak kehilangan pamornya. Pada masa akhir Perang Dunia II muncul gerakan untuk menghidupkan kembali teori hak kodrati di masyarakat internasional. Pengalaman buruk dunia internasional dengan peristiwa Holocaust Nazi, membuat dunia berpaling kembali kepada gagasan John Locke tentang hakhak kodrati. Setelah kebiadaban luar biasa terjadi menjelang maupun selama Perang Dunia II, gerakan untuk menghidupkan kembali hak kodrati menghasilkan rancangan instrumen internasional utama mengenai hak asasi manusia. Hal ini dimungkinkan dengan terbentuknya Perserikatan Bangsa-Bangsa (PBB) pada 1945, yang menegaskan kembali kepercayaan terhadap HAM, terhadap martabat dan kemuliaan manusia, terhadap kesetaraan hak-hak laki-laki dan perempuan, dan kesetaraan negara besar dan kecil. Dari sinilah dimulai internasionalisasi gagasan HAM. Sejak saat itulah masyarakat internasional 
bersepakat menjadikan HAM sebagai "suatu tolok ukur pencapaian bersama bagi semua rakyat dan semua bangsa" ("a commond standard of achievement for all peoples and all nations"). Hal ini ditandai dengan diterimanya oleh masyarakat internasional suatu rezim hukum hak asasi manusia internasional yang disiapkan oleh PBB atau apa yang kemudian lebih dikenal dengan "International Bill of $\mathrm{Hu}$ man Rights" (Rhona K.M. Smith, dkk, 2008: 12-15).

Dengan demikian, teori hak kodrati yang muncul karena adanya hukum alam yang merupakan landasan atau dasar bagi setiap negara untuk melindungi HAM setiap individu, dalam hal ini adalah warga negaranya, baik yang berdomisili di dalam maupun diluar wilayahnya. Teori hak kodrati membebankan kewajiban kepada negara untuk melindungi HAM warga negaranya, dimana dalam konsep hukum alam, negara adalah wakil Tuhan di dunia yang diberikan mandat untuk melindungi hak kodrati setiap warganya, sehingga apapun yang dilakukan negara adalah semata-mata untuk untuk melindungi hakhak kodrati setiap individu, seperti hak untuk hidup, kekebasan, keamanan, kekayaan, kebahagiaan dan lain sebagainya. Teori hak-hak kodrati ini muncul sebagai reaksi masyarakat atas otoritas penguasa yang absolut pada masa itu. Melalui teori 'kontrak sosial' (social contract), yang dikembangkan oleh Locke, perlindungan atas HAM setiap individu diserahkan kepada negara. Tetapi, apabila penguasa negara mengabaikan kontrak sosial itu dengan melanggar hakhak kodrati individu, maka rakyat di negara itu bebas menurunkan sang penguasa dan menggantikannya dengan suatu pemerintah yang bersedia menghormati hak-hak tersebut.

b. Pergeseran Makna Prinsip Kedaulatan Negara

Kedaulatan dalam bahasa Inggris dikenal dengan istilah souvereignty yang berasal dari kata latin superanus yang berarti yang teratas. Berdasarkan asal katanya tersebut, kedaulatan diartikan sebagai kekuasaan tertinggi. Kedaulatan negara berarti kekuasaan tertinggi dalam negara;negara memiliki monopoli kekuasaan; suatu sifat khas organisasi masyarakat yang tidak membenarkan or- ang lain mengambil tindakan sendiri apabila ia dirugikan. Namun demikian, ruang lingkup kekuasaan tertinggi tersebut dibatasi oleh batas wilayah negara tersebut, artinya bahwa suatu negara hanya memiliki kekuasaan tertinggi di dalam batas wilayahnya sendiri. Dengan demikian, pengertian kedaulatan negara sebagai kekuasaan tertinggi mengandung dua pembatasan penting, yaitu kekuasaan itu terbatas pada wilayah negara yang memiliki kekuasaan itu dan kekuasaan itu berakhir ketika berhadapan dengan kekuasaan negara lain (Mochtar Kusumaatmadja, Etty R Agoes, 2003: 1618).

Konsep kedaulatan negara modern berkembang pesat sejak ditandatanganinya Perjanjian Westphalia 1684 yang telah mengakhiri 80 konflik agama yang terjadi di Eropa dan menghasilkan ketentuan baru hukum internasional yang mendasari terbentuknya sistem negara modern. Dasar dan sistem negara modern tersebut adalah pengakuan atas karakter berdaulat dari suatu negara dan menolak adanya campur tangan oleh pihak luar dalam masalah internal. Konsep ini menciptakan tatanan dan stabilitas di dalam hubungan internasional karena negara-negara berdaulat, di bawah sistem Westphalian, negara dipandang setara, tanpa memandang ukuran atau kekayaan yang berbeda-beda satu sama lain. Prinsip kedaulatan yang setara dari semua negara adalah salah satu prinsip dasar di dalam Piagam PBB (perjanjian yang ditetapkan oleh PBB pada tahun 1945). Sebuah negara berdaulat memiliki yurisdiksi atau kontrol penuh atas wilayah kekuasaannya. Di bawah sistem kedaulatan negara, negara-negara lain tidak semestinya melakukan intervensi di dalam urusan internal dari negara lain.

Namun demikian, sedikit demi sedikit konsep kedaulatan westphalia yang menolak adanya intervensi urusan internal negara tersebut oleh pihak lain mulai bergeser pada abad 20. Pada abad ini sejarah menunjukkan bahwa banyak sekali pembunuhan dan kekejajaman yang dilakukan oleh negara. Puluhan juta manusia telah tewas dibunuh, disiksa, kelaparan dan meregang nyawa di berbagai belahan dunia akibat kejahatankejahatan yang dikenal sebagai 
pemusnahan massal, kejahatan perang, kejahatan terhadap kemanusiaan dan pembersihan etnis. Selama Perang Dunia (PD) Pertama, pembunuhan massal terhadap orang-orang Armenia telah memakan korban jiwa sebesar lebih dari satu juta orang. Kemudian, pada PD II rejim Nazi menewaskan 11 juta orang, termasuk 6 juta orang Yahudi dan juga jutaan tawanan perang dan orang Gipsi. Di Kamboja, hampir dua juta manusia dibunuh di bawah rejim pemerintahan Khmer Merah yang dipimpin oleh Pol Pot. Di banyak negara lainnya juga, berbagai pembunuhan terjadi terhadap kaum sipil, seperti di Guatemala dan Bangladesh. Pada dekade 1990-an, dunia kembali dikejutkan dengan pembunuhan massal yang terjadi di Bosnia dan Rwanda, lebih dari satu juta orang tewas dibunuh dan komunitas internasional gagal untuk mencegah terjadinya pemusnahan massal.

Berdasarkan realitas sejarah tersebut, pemaknaan prinsip kedaulatan negara westphalia yang tidak menghendaki adanya campur tangan atau intervensi urusan internal suatu negara mulai bergeser. Dalam tatanan kenegaraan, pemerintah sebagai otoritas tertinggi dalam suatu negara sebelumnya hanya bertanggungjawab atas kewajiban antar negara, tetapi sejak diterimanya HAM konsep kedaulatan westphalia mulai bergeser, ketentuan HAM internasional yang baru membentuk seperangkat norma yang dimaksudkan untuk mengatur hubungan pemerintah dengan rakyatnya. Negara oleh sejumlah instrumen HAM internasional dilekati kewajiban yaitu berkewajiban menghormati (melaksanakan melindungi HAM negaranya. Kewajiban-kewajiban yang dibebankan instrumen HAM internasional terhadap negara-negara tersebut harus dilaksanakan negara dengan prinsip effectiveness, yaitu negara harus melakukan langkah-langkah yang positif dalam kerangka menjamin HAM warga negaranya, baik melalui upaya pemajuan maupun perlindungan HAM (penegakan hukumnya). Jaminan perlindungan HAM tersebut berlaku untuk seluruh warga negaranya di manapun ia berada, dan tidak terbatas pada warga negara nya saja, tetapi juga terhadap orang asing di wilayah teritorialnya.
Dalam konteks hubungan kedaulatan negara dengan HAM, ketika negara tidak melaksanakan kewajiban-kewajiban yang dibebankan oleh hukum internasional tersebut, baik berkewajiban menghormati melaksanakan melindungi HAM negaranya, sistem hukum internasional menyediakan mekanisme monitoring dan enforcement sampai pada pengadilan HAM internasional. Hal ini merupakan wujud bahwa kedaulatan negara sekarang tidaklah mutlak merupakan kekuasaan tertinggi yang tidak dapat diintervensi pihak lain. Dalam konteks HAM, konsep kedaulatan, konsep imunitas negara dapat disimpangi ketika negara tidak melaksanakan atau melanggar kewajibankewajiban yang dibebankan oleh hukum internasional untuk melakukan pemajuan dan perlindungan HAM. Pergeseran konsep kedaulatan inilah yang kemudian mendasari setiap negara untuk melindungi HAM warga negaranya, tanpa ada suatu diskriminasi apapun.

c. Prinsip the Exhaustion of Local Remedies dalam Mekanisme Penegakan HAM

Hukum HAM internasional mengenal prinsip "exhaustion of local remedies", yang mengharuskan penggunaan seoptimal mungkin semua upaya hukum yang tersedia di tingkat nasional terlebih dahulu sebelum menggunakan mekanisme remedi di tingkat regional dan internasional dalam kerangka penegakan HAM. Jadi mekanisme pemenuhan dan penegakan internasional hanya diperlukan apabila mekanisme remedi nasional tidak bekerja secara efektif, sehingga korban yang merasa belum mendapatkan keadilan.. Pengadilan nasional merupakan pintu pertama yang harus dilalui dalam usaha menagih pertanggungjawaban bagi pelanggaran berat hak asasi manusia. Pengadilan internasional tidak dapat serta merta menggantikan peran pengadilan nasional, tanpa melewati pengadilan nasional suatu negara. Jadi peran pengadilan internasional (apakah yang permanen atau ad hoc) hanya bersifat komplementer, artinya melengkapi proses pertanggungjawaban ditingkat nasional. Kalau proses di dalam negeri sudah berjalan dengan memuas, maka peran pengadilan internasional tidak diperlukan lagi. Kecuali proses yang berjalan di dalam pengadilan nasional lebih ditujukan untuk 
melindungi tersangka (atau dijalankan dengan tidak jujur), maka terbuka bagi pengadilan internasional mengambil perannya. Prinsip ini juga dikuatkan dalam statuta Roma mengenai Mahkamah Pidana Internasional. Dengan demikian, prinsip exhaustion of local remedies mengisyaratkan bahwa negara memiliki tugas yang utama dalam pemenuhan dan penegakan hukum HAM. Hal ini disebabkan, mekanisme pemenuhan dan penegakan HAM di tingkat nasional pintu pertama yang harus dilalui dalam usaha menagih pertanggungjawaban seseorang ketika melakukan pelanggaran berat hak asasi manusia.

Munculnya prinsip exhaustion of local remedies ini banyak diilhami oleh konsep the functional theory of international law. Penulis mengidentifikasi bahwa fungsi hukum internasional hampir sama dengan konsep fungsi hukum pada umumnya. Hukum paling sedikit berfungsi untuk mencapai dua target utama yaitu ketertiban umum dan untuk mewujudkan keadilan (Budiono Kusumohamidjojo, 2004: 166). Ketertiban umum merupakan suatu keadaan yang menyiratkan suatu keteraturan yang diterima umum sebagai suatu kepantasan minimal yang diperlukan, supaya kehidupan bersama tidak berubah menjadi anarki. Hukum dapat mempertahankan tertib hukum itu hanya jika hukum itu berhasil menjaga keseimbangan antar kepentingan manusia yang selalu bertentangan satu sama lain. Artinya, tertib hukum itu hanya dapat ditegakkan jika hukum itu mendatangkan keadilan, yaitu melindungi kepentingan dan cita-cita dasar manusia bagi mereka yang berkepentingan terhadap tertib hukum itu (Budiono Kusumohamidjojo, 2004: 170-171). Dengan demikian, hukum juga berfungsi sebagai alat pelindungan kepentingan manusia, dimana agar kepentingan tersebut dapat terlindungi, hukum harus dilaksanakan secara professional, sehingga akan terwujud tujuan hukum yaitu keadilan, kepastian dan kemanfaatan hukum bagi masyarakat.

Dalam konteks hukum internasional, beberapa penulis telah mengkaji fungsi hukum internasional, di antaranya Hersch Lauterpacht dalam artikelnya "The Function of Law in the International Community" menyatakan bahwa fungsi hukum internasional tidak lebih selain fungsi pengadilan. Philip Allott mendeskripsikan bahwa The true function of law in the international community is precisely the same as the true function of law in any human society (Philip Allott, 1998:396). Oleh Kelsen, fungsi esensial hukum internasional adalah untuk menentukan ruang lingkup validitas hukum nasional, termasuk dalam menentukan wilayah teritorialnya, orang, barang dan waktu.

Oleh karena itu, agar hukum internasional dapat berfungsi sebagai alat perlindungan kepentingan dan menjaga ketertiban umum dalam masyarakat, hukum harus dilaksanakan secara professional sehingga akan terwujud tujuan hukum yaitu keadilan, kepastian dan kemanfaatan hukum bagi masyarakat. Selanjutnya, dalam konsep hukum internasional mengenai hubungan antara hukum internasional dan hukum nasional, berdasarkan prinsip kedaulatan negara, maka hubungan antara keduanya bersifat koordinasi. Hal demikian berarti bahwa kedudukan antara hukum internasional dan hukum nasional adalah setara, tidak ada hukum yang lebih tinggi. Dengan demikian, mekanisme penegakan hukum internasional biasanya menggunakan mekanisme penegakan di tingkat nasional terlebih dahulu. Berdasar konsep pemenuhan dan penegakan HAM, maka mekanisme pemenuhan dan penegakannya menggunakan mekanisme di tingkat nasional terlebih dahulu sebelum dibawa ke mekanisme regional atau internasional. Konsep inilah yang dikenal dengan prinsip exhausted of local remedies.

Berdasarkan prinsip exhaustion of local remedies, negara memiliki tugas yang utama dalam pemenuhan dan penegakan hukum HAM. Oleh karena itu, tersedianya sebuah mekanisme penegakan yang efektif di tingkat nasional menjadi tanggung jawab setiap negara dalam kerangka pemajuan dan perlindungan HAM warga negaranya. Hal demikian karena mekanisme pemenuhan dan penegakan HAM di tingkat nasional merupakan pintu pertama yang harus dilalui dalam usaha menagih pertanggungjawaban seseorang ketika melakukan pelanggaran berat HAM, sehingga negara harus dibebankan kewajiban untuk melindungi HAM warga negaranya dan 
memastikan berbagai upaya penegakan HAM ditingkat nasional sebagaimana implementasi dari prinsip exhaustion of local remedies dapat terlaksana secara efektif.

d. Prinsip Pacta Sunt Servanda

Terkait penegakan hukum internasional, kewajiban-kewajiban yang dibebankan terhadap subyek-subyek hukumnya termasuk salah satunya negara dikaitkan dengan kewajiban moral. Negara dengan etikat baiknya melaksanakan semua ketentuan-ketentuan hukum internasional baik yang muncul karena perjanjian internasional, hukum kebiasaan internasional, prinsip hukum umum ataupun kaedah-kaedah hukum internasional lainnya yang disetujui oleh masyarakat internasional (Sumaryo Suryokusumo, 2003: 1). Dalam hal perjanjian internasional, negara-negara terikat kewajiban untuk melaksanakan karena adanya prinsip mendasar yaitu prinsip pacta sunt servanda. Prinsip ini merupakan salah satu dari prinsip hukum internasional paling tua yang mengandung arti bahwa setiap perjanjian mengikat para pihak perjanjian tersebut dan harus dilaksanakan oleh mereka dengan itikad yang baik. Perjanjian itu harus dilaksanakan, walaupun ada perbedaan pendapat mengenai sifat aturan yang absolut dan persyaratan yang menurut hukum mungkin dapat dikesampingkan. Menurut prinsip ini negara terikat melaksanakan kewajiban-kewajibannya dengan itikad sesuai perjanjian tersebut (Sumaryo Suryokusumo, 2003: 2). Prinsip pacta sunt servanda ini merupakan prinsip mendasar dalam hukum internasional . Prinsip ini kemudian telah dimasukkan dalam Konvensi Wina 1969 mengenai Hukum Perjanjian yang menyatakan bahwa: "Setiap perjanjian yang berlaku adalah mengikat para pihak perjanjian tersebut dan harus dilaksanakan oleh mereka dengan tikad baik".

Instrumen-instrumen HAM internasional, dalam hal ini adalah perjanjian internasional membebankan kewajibankewajiban kepada negara, antara lain tercantum dalam Pasal 2 Kovenan Internasional Hak-hak Ekonomi, Sosial dan Budaya; Kovenan Internasional Hakhak Sipil dan Politik; Konvensi Internasional Penghapusan Segala Bentuk
Diskriminasi Rasial; Konvensi Penghapusan Segala Bentuk Diskriminasi terhadap Perempuan; Konvensi Menentang Penyiksaan dan Perlakuan atau Penghukuman Lain yang Kejam, Tidak Manusiawi dan Merendahkan Martabat Manusia; serta Pasal 4 Konvensi Hak Anak. Secara umum masing-masing pasal dalam instrumen-instrumen HAM internasional juga membebankan kewajiban kepada negara-negara anggota untuk menghormati menjamin melaksanakan HAM yang diatur dalam instrumen-instrumen HAM tersebut.

Dengan demikian, berdasarkan prinsip pacta sunt servanda maka negaranegara terikat pada konvensi-konvensi HAM internasional tersebut mempunyai kewajiban hukum dan moral untuk melaksanakan setiap kewajiban yang diatur dalam konvensi, diantaranya yaitu , yaitu kewajiban untuk menghormati (duty to respect), kewajiban untuk menjamin (duty to ensure) dan kewajiban untuk menegakkan (duty to enforce/protect) HAM. Oleh karena itu, prinsip pacta sunt servanda menjadi dasar bagi setiap negara untuk memberikan perlindungan HAM kepada seluruh warga negaranya walaupun mereka tidak berdomisili di dalam wilayahnya. Indonesia sebagai negara peratifikasi instrumen-instrumen HAM initernasional, oleh karenanya berdasarkan prinsip pacta sunt servanda, Indonesia dibebankan kewajiban untuk melindungi HAM warga negaranya.

e. Prinsip Nasional/Kewarganegaraan Indonesia

Di Indonesia, konsep perlindungan terhadap warga negara terdapat dalam Pembukaan UUD Negara Republik Indonesia, khususnya pada alenia keempat yaitu tentang tujuan negara. Adapun empat tujuan atau cita-cita ideal Negara Indonesia yaitu: (i) melindungi segenap bangsa Indonesia dan seluruh tumpah darah Indonesia; (ii) meningkatkan kesejah-teraan umum; (ii) mencerdaskan kehidupan bangsa; dan (iv) ikut melaksanakan ketertiban dunia berdasarkan kemerde-kaan, perdamaian yang abadi, dan keadilan sosial.

Dalam rangka mencapai keempat tujuan yang merupakan cita-cita ideal bangsa Indonesia, khususnya dalam rangka melindungi segenap Bangsa Indo- 
nesia dan seluruh tumpah darah Indonesia, memunculkan prinsip yang disebut dengan prinsip nasionalitas atau kewarganegaraan. Prinsip nasionalitas ini dibedakan menjadi dua yaitu prinsip nasionalitas aktif dan pasif. Rasionalitas prinsip ini bahwa negara dan warga negaranya tetap mempunyai hubungan/ ikatan walaupun warga negara Indonesia tersebut tidak berada di wilayah Indonesia, dalam artian warga negara tersebut tidak berdomisili di Indonesia karena bekerja atau menempuh pendidikan di luar negeri. Dapat disimpulkan bahwa asas nasionalitas ini tetap melekat pada warga negara Indonesia dimanapun ia berada, demikian juga bahwa Indonesia sebagai negara yang selalu mempunyai ikatan dengan warga negaranya harus tetap memberikan perlindungan dimanapun mereka berada. Berdasarkan prinsip ini setiap negara wajib untuk memberikan perlindungan sepenuhnya terhadap warga negaranya,walaupun warga negaranya itu berada di luar negeri.

Berdasarkan konsep prinsip nasionalitas yang melekat pada Negara Indonesia dan Warga Negara Indonesia, maka dalam konteks perlindungan HAM pekerja migran perempuan, negara berkewajiban untuk memberikan perlindungan terhadap pekerja migran perempuan. Bentukbentuk perlindungan tersebut dapat diwujudkan dalam bentuk pengaturan secara normatif dalam perundangundangan yang berpihak pada pekerja migran maupun fasilitasi-fasilitasi lain yang diperlukan dalam rangka menjamin pelaksanaan kewajiban negara dalam melindungi HAM pekerja migran, khususnya perempuan karena mereka adalah kelompok yang rentan akan pelanggaran HAM.

4. Norma-norma tentang Kewajiban Negara Indonesia dalam Melindungi Pekerja Migran Perempuan

Norma merupakan perumusan suatu pandangan obyektif mengenai penilaian atau sikap yang seyogyanya dilakukan atau tidak dilakukan, yang dilarang atau dianjurkan untuk dilakukan. Dalam arti sempit norma adalah nilai yang terdapat dalam peraturan konkrit (Sudikno Mertokusumo, 2007: 5-11). Norma-norma yang membebankan kewajiban kepada negara untuk memberikan jaminan perlindungan HAM bagi pekerja migran perempuan akan diuraikan baik yang berasal dari norma hukum internasional maupun norma hukum nasional.

a. Konvensi Migrasi untuk Pekerjaan (Revisi), 1949 (No. 97)

Konvensi No. 97 memuat sejumlah ketentuan yang dirancang untuk membantu para migran untuk bekerja. Misalnya, konvensi ini menyerukan negara-negara agar setelah meratifikasi konvensi ini memberikan informasi yang relevan pada negara anggota ILO yang lain dan organisasi itu sendiri, untuk mengambil langkah-langkah melawan propaganda menyesatkan, dan memfasilitasi keberangkatan, perjalanan, dan juga penerimaan para migran. Konvensi ini juga meminta negara-negara yang telah meratifikasi konvensi agar memposisikan migrant yang secara sah berada dalam wilayahnya, dengan perlakuan yang sama seperti warganegaranya sendiri dalam menerapkan berbagai hukum dan peraturan yang berkenaan dengan kehidupan kerja mereka, tanpa diskriminasi berdasarkan kewarganegaraan, ras, agama ataupun jenis kelamin.

Konvensi ini bertujuan untuk: 1) mengatur kondisi-kondisi dimana migrasi perburuhan terjadi; dan 2) memberikan perlindungan khusus untuk kategori pekerja yang sangat rentan sementara mereka dipekerjakan di negara-negara lain di luar negaranya sendiri. Konvensi tersebut tidak membedakan antara migran yang permanen atau sementara. Meskipun demikian, ketentuan-ketentuan tertentu dalam Konvensi No. 97 hanya terkait dengan pekerja-pekerja migran dan keluarga-keluarga mereka yang telah diterima secara permanen, misalnya ketentuan yang melindungi pekerjapekerja ini terhadap pemulangan hanya berdasarkan ketidakmampuan untuk bekerja. Konvensi ini meliputi mereka yang diterima secara reguler sebagai migran untuk pekerjaan. Konvensi ini mencakup langkah-langkah untuk mengatur kondisi-kondisi dimana terjadi migrasi untuk pekerjaan, seperti: 1) langkah-langkah perlindungan umum terkait pemberian layanan-layanan gratis untuk membantu migran; 2) akses informasi; 3) langkah-langkah menanggapi propaganda yang menyesatkan, 
perjalanan, dan kedatangan migran, transfer pendapatan mereka; dan 4) langkah-langkah yang terkait dengan pemulangan pekerja migran secara permanen. Konvensi ini menyediakan langkah-langkah yang bertujuan untuk memastikan kesetaraan perlakuan antara pekerja migran reguler dan warga negara sehubungan jaminan sosial, kondisi pekerjaan dan kondisi hidup, pajak pekerjaan dan akses keadilan. Konvensi ini menuntut implementasi kebijakan kesetaraan perlakuan antara warga negara dan pekerja migran reguler. Kategorikategori migran yang tidak termasuk dalam cakupan konvensi ini adalah: 1) pelaut; 2) pekerja di garis perbatasan ; 3) anggota profesi liberal atau artis yang masuk untuk jangka waktu yang pendek; dan 4) mereka yang mempekerjakan diri sendiri dan tidak tercakup dalam konvensi ini.

b. Konvensi Pekerja Migran (KetentuanKetentuan Tambahan), 1975 (No. 143)

Konvensi Konvensi no. 143 dalam bagian I nya membahas masalah migrasi dalam kondisi teraniaya, dan bagian II mengenai persamaan kesempatan dan perlakuan. Negara-negara yang telah meratifikasi konvensi ini mempunyai pilihan untuk menerima keseluruhan instrumen, atau salah satu dari kedua bagian tersebut. Konvensi ini menentukan bahwa negara-negara peratifikasi harus menghormati hak asasi mendasar dari semua pekerja migran. Mereka juga harus mencegah terjadinya migrasi gelap, dan menghentikan kegiatan perdagangan manusia. Selanjutnya, negara-negara peratifikasi harus menetapkan dan memberlakukan kebijakan untuk menjamin diberikannya perlindungan yang sama dalam hal pekerjaan dan perburuhan, jaminan sosial, serikat pekerja dan hak budaya.

Konvensi ini bertujuan untuk: 1) mengatur kondisi-kondisi dimana migrasi perburuhan terjadi; dan 2) memberikan perlindungan khusus untuk kategori pekerja yang sangat rentan sementara mereka dipekerjakan di negara lain diluar dari negara mereka sendiri. Konvensi ini merupakan upaya pertama yang dilakukan oleh komunitas internasional untuk menangani masalah-masalah yang timbul dari migrasi ireguler dan pekerjaan ilegal bagi para migran. Konvensi ini mencakup ketentuan-ketentuan untuk standarstandar perlindungan minimum baik untuk pekerja migran reguler maupun ireguler. Tanpa menantang hak negara untuk mengatur arus migrasi, Konvensi ini menetapkan kewajiban umum bagi negara untuk: 1) menghormati hak-hak asasi manusia dasar bagi semua pekerja migran; 2) menyediakan langkah-langkah perlindungan khusus untuk pekerja migran yang telah kehilangan pekerjaan mereka dan bagi mereka yang berada dalam situasi-situasi ireguler. Konvensi tersebut menegaskan: a) untuk mengatur arus migrasi; dan b) hak pekerja-pekerja migran untuk dilindungi, baik apabila mereka memasuki negara tersebut secara reguler atau tidak, dengan atau tanpa dokumendokumen resmi. Konvensi tersebut juga menekankan pentingnya berkonsultasi pada perwakilan-perwakilan organisasiorganisasi pengusaha dan pekerja sehubungan dengan hukum, peraturan dan langkah-langkah lain yang diberikan, dan dirancang untuk mencegah dan menghapuskan migrasi dalam kondisikondisi yang diwarnai dengan penyelewengan.

Konvensi ini menuntut pemberlakuan ketentuan kesetaraan kesempatan sehubungan dengan akses migran terhadap pekerjaan, hak-hak serikat pekerja, hak-hak budaya dan kebebasankebebasan individual dan kelompok. Meskipun demikian, Konvensi ini juga mengijinkan pembatasan yang terbatas pada kesetaraan kesempatan dalam akses pekerjaan. Kebijakan nasional yang diharuskan dalam Konvensi ini tidak hanya harus mempromosikan tetapi juga harus menjamin kesetaraan kesempatan dan perlakuan dalam pekerjaan dan jabatan bagi para pekerja migran dan anggotaanggota keluarga mereka yang berada di wilayah teritorial negara dimana mereka bekerja secara legal. Kategori-kategori migran yang dikecualikan dari cakupan Konvensi ini adalah: (1) pelaut, (2) pekerjapekerja di wilayah perbatasan (3) anggotaanggota profesi liberal dan artis-artis yang masuk untuk jangka waktu yang pendek; dan (4) mereka yang mempekerjakan diri sendiri. 
c. United Nations Convention on The Protection of The Rights of All Migran Workers and Member of Their Families tahun 1990.

Dalam rangka pengaturan dan perlindungan HAM pekerja migran dalam hukum internasional, salah satu perkembangan yang paling signifikan adalah dengan dibentuknya United $\mathrm{Na}$ tions Convention on The Protection of The Rights of All Migran Workers and Member of Their Families tahun 1990. Terobosan utama Konvensi Internasional tentang Perlindungan Hak Semua Pekerja Migran dan Anggota Keluarganya adalah bahwa orang-orang yang memenuhi kualifikasi sebagai pekerja migran sesuai ketentuan-ketentuannya, berhak untuk menikmati hak asasi manusia apapun status hukumnya. Konvensi ini berlaku terhadap semua pekerja migran dan anggota keluarga mereka, terlepas dari jenis kelamin, ras, warna kulit, bahasa, agama/keyakinan, pendapat politik atau pendapa lainnya, asal kewarganegaraan, etnis, suku, status pernikahan, kelahiran, atau status lainnya. Perlindungannya mencakup semua proses migrasi-dari sebelum keberangkatan, keberangkatan, transit, tinggal, pekerjaan, dan proses kembali ke daerah asal.

Bagian VI Konvensi ini menetapkan sejumlah kewajiban pada negara-negara pihak dengan maksud memajukan "kondisi yang baik, setara, manusiawi dan berdasar hukum," bagi migrasi internasional pekerja migran dan anggota keluarganya. Persyaratan ini mencakup pembuatan kebijakan tentang migrasi; pertukaran informasi dengan negaranegara pihak lainnya; ketentuan mengenai informasi pada para majikan, pekerja dan organisasinya mengenai kebijakan, hukum dan peraturan-peraturan; dan bantuan pada pekerja migran dan anggota keluarganya. Konvensi ini juga menetapkan sejumlah aturan bagi rekrutmen pekerja migran, dan bagi kepulangan mereka ke negara asal. la juga merinci langkah-langkah yang harus diambil untuk memberantas migrasi gelap dan ilegal

\section{Simpulan}

Berdasarkan hasil penelitian dan pembahasan maka dapat disimpulkan bahwa prinsip-prinsip hukum umum yang menjadi dasar Indonesia terkait kewajibannya memberikan perlindungan HAM pekerja migran perempuan adalah prinsip nasionalitas/kewarganegaraan Indonesia, prinsip pacta sunt servanda, prinsip exhaustion of local remedies, pergeresan makna prinsip kedaulatan dan diakuinya prinsip teori hak-hak kodrati yang melekat dalam diri setiap manusia. Selanjutnya, norma-normanya terdapat dalam Konvensi Migrasi untuk Pekerjaan (Revisi), 1949 (No. 97), Konvensi Pekerja Migran (Ketentuan-Ketentuan Tambahan), 1975 (No. 143), United Nations Convention on The Protection of The Rights of All Migran Workers and Member of Their Families tahun 1990, UUD 1945 UU No 39 Tahun 1999 tentang HAM, UU No 39 Tahun 2004 tentang Penempatan dan Perlindungan TKI di Luar Negeri, Inpres No 6 Tahun 2006 tentang Kebijakan Reformasi Sistem Penempatan dan Perlindungan TKI, Peraturan Presiden Nomor 81 Tahun 2006 tentang Pembentukan BNP2TKI.

\section{E. Saran}

Berdasarkan simpulan, Indonesia berkewajiban memberikan perlindungan HAM secara optimal kepada pekerja migran perempuan. Untuk lebih mengoptimalkan perlindungan HAM pekerja migran Indonesia perlu segera melakukan revisi atas UU No 39 tahun 2004 tentang Penempatan dan Perlindungan Tenaga Kerja Indonesia di Luar Negeri karena Indonesia baru meratifikasi International Convention on the Protection of the Rights of All Migrant Workers and Members of Their Families, 1990. Setelah diratifikasinya Konvensi Migran 1990, maka konvensi ini akan menjadi acuan perbaikan peraturan perudang-undangan nasional yang berkaitan dengan buruh migran berbasiskan standar HAM Internasional. 


\section{DAFTAR PUSTAKA}

Budiono Kusumohamidjoyo. 2004. Filsafat Hukum, Probkematik Ketertiban yang Adil. Jakarta: Grasindo

International Organization of Migration. 2010. Migrasi Tenaga Kerja dari Indonesia. IOM: Jakarta.

Konvensi Migrasi untuk Pekerjaan (Revisi), 1949 (No. 97).

Konvensi Pekerja Migran (Ketentuan-Ketentuan Tambahan), 1975 (No. 143).

Manfred Nowak. 2003. Introduction to the International Human Rights Regim. Martinus Nijhoff Publisher: Leiden.

Jennifer S. Hainsfurther. 2008. " A Rights-Based Approach: The Utilization of Cedaw to Protect the Human Rights of Migrant Workers". American University International Law Review.

Jerome J. Shestack dalam Rhonda L. Callaway. 2007. Exploring International Human Rights: Essensial Readings: United State of America: Lynne Rienner Publisher

Jorge Bustamante. 2006. Report of the Special Rapporteur on the human rights of migrans. Human Rights Countil

Manisuli Ssenyonjo. 2009. Economic, Social and Cultural Rights in International Law. North America (US and Canada): Hart Publishing.

Majna El Muhtaj. 2008. Dimensi-dimensi HAM, Mengurai Hak Ekonomi, Sosial dan Budaya. Jakarta: PT Rajagrafindo Persada.

Mattias Kumm. 2004. The Legitimacy of International Law: A Constitutionalist Framework of Analysis. The European Journal of International Law Vol. 15 no.5.

Margaret L. Satterthwaite. 2005. Crossing Borders, Claiming Rights: Using Human Rights Law to Empower Women Migrant Workers. Yale Human Rights and Development Law Journal.

Mochtar Kusumaatmadja, Etty R Agoes. 2003. Pengantar Hukum Internasional. Bandung: Penerbit PT Alumni.

Peter Mahmud Marzuki. 2005. Penelitian Hukum. Jakarta: Prenada Media. Perpres No 81 Tahun 2006 tentang Pembentukan BNP2TKI

Philip Allott. 1998. "The True Function of Law in The International Community". Indiana Journal of Global Legal Studies. Spring. 1998

Rhona KM Smith. 2008. Hukum Hak Asasi Manusia. Yogyakarta: Pusat Studi Hak Asasi Manusia Univer- sitas Islam Indonesia.

Rhonda L. Callaway. 2007. Exploring International Human Rights: Essential Readings. USA: Lynne Rienner Publisher

Soemaryo Suryokusumo. 2003. "Aspek Moral dan Etika dalam Penegakan Hukum Internasional". Makalah. Seminar tentang "Pembangunan Hukum Nasional VIII diselenggarakan oleh Badan Pembinaan Hukum Nasional Departemen Kehakiman dan HAM, Denpasar, 14-18 Juli 2003. Sudikno Mertokusumo. 2007. Mengenal Hukum. Yogyakarta: Liberty.

Soetandyo Wignjosoebroto. 2002. Hukum Paradigma, Metode dan Dinamika Masalahnya. Jakarta : Elsam dan Huma

UN Convention on The Protection of The Rights of All Migran Workers and Member of Their Families tahun 1990. 